\title{
Ecology and Conservation of the Laotian langur Trachypithecus laotum in a Protected Area of Laos (Southeast Asia)
}

\author{
Johnny Souwideth ${ }^{1} \mathbb{D}$, Phaivanh Phiapalath ${ }^{2}$, Hai Dong Thanh ${ }^{1}$, Peter Brakels ${ }^{3}$, Thong Pham Van ${ }^{4} \mathbb{C}$ and \\ Luca Luiselli $5,6,7, * \mathbb{C}$
}

1 Vietnam National University of Forestry, Street 21, Xuan Mai Town, Chuong My District, Hanoi 100000, Vietnam; johnnyblack1991@gmail.com (J.S.); donghaifuv@gmail.com (H.D.T.)

2 Freelance Consultant, Vientiane, Laos; p.phiapalath@gmail.com

3 IUCN Vientiane Office, 391/24 Bourichane Road, Ban Naxay, Sayshetta District, Vientiane, Laos; peter.brakels@iucn.org

4 Save Vietnam's Wildlife, Cuc Phuong National Park, Cuc Phuong Commune, Nho Quan 430000, Vietnam; thong@svw.vn

5 Institute for Development, Ecology, Conservation and Cooperation, Via G. Tomasi di Lampedusa 33, 00144 Rome, Italy

6 Department of Applied and Environmental Biology, Rivers State University of Science and Technology, P.M.B. 5080 Port Harcourt, Nigeria

7 Département de Zoologie et Biologie Animale, Faculté des Sciences, Université de Lomé, B.P. 1515 Lomé, Togo

* Correspondence: 1.luiselli@ideccngo.org

Citation: Souwideth, J.; Phiapalath, P.; Thanh, H.D.; Brakels, P.; Van, T.P.; Luiselli, L. Ecology and Conservation of the Laotian langur Trachypithecus laotum in a Protected Area of Laos (Southeast Asia). Diversity 2021, 13, 231. https://doi.org/10.3390/ d13060231

Academic Editor: Michael Wink

Received: 27 April 2021

Accepted: 19 May 2021

Published: 25 May 2021

Publisher's Note: MDPI stays neutral with regard to jurisdictional claims in published maps and institutional affiliations.

Copyright: (c) 2021 by the authors. Licensee MDPI, Basel, Switzerland. This article is an open access article distributed under the terms and conditions of the Creative Commons Attribution (CC BY) license (https:// creativecommons.org/licenses/by/ $4.0 /)$.
Abstract: Terrestrial species from the Lao People's Democratic Republic (PDR) are under high threat due to deforestation and overhunting. Previous studies have even defined these forests as subjected to an "empty forest syndrome", a condition in which forests that are apparently well preserved are instead almost deprived of vertebrate faunas due to extreme exploitation by local communities. Forest specialists, including several primates, are among the most threatened species in the country. The Laotian langur (Trachypithecus laotum) is endemic to Lao PDR, is listed as Endangered by the IUCN Red List, and it is one of the least studied species in the region. A survey on the local distribution, life history and conservation status of the Laotian langur was carried out in Phou Hin Poun National Protected Area, Khammouane Province of Lao PDR. The survey consisted of an initial phase with interviews to select key informants on the Laotian langur and the other primate species of the area. Then, a phase of field surveys along forest transects, totaling $64.1 \mathrm{~km}$ of 21 transects, yielded a record of 35 individuals in 9 groups. The highest encounter/detection rate of the Laotian langur was 1 group per $\mathrm{km}$ at one sector of the park. In contrast, it was much lower $(0.18-0.34$ groups $/ \mathrm{km})$ in the rest of the protected area. The group sizes were much lower than those observed in the same area between 1994 and 2010, thus suggesting a decline in the population size of langurs. This decline may be linked to habitat loss (timber extraction and mining). Still, also overhunting, as signs of poaching were observed during our field surveys. This was also supported by the reports of our interviewees. Laotian langurs were observed to be sympatric and interact while foraging with the Assamese macaque (Macaca assamensis). In the cases of sympatric occurrence between the two species, we observed that subtle mechanisms of niche partitioning may occur to reduce interspecific competition for food. Further research on the population and ecology of this endangered langur should be conducted to understand the species and aid its conservation.

Keywords: primates; Laotian langur; Assamese macaque; Phou Hin Poun National Protected Area; surveys; ecology; conservation; interspecific interactions

\section{Introduction}

Extensive forest loss and overhunting are among the main threats affecting biodiversity worldwide, particularly in the megadiverse tropical countries [1-4]. Deforestation and logging rates have dramatically accelerated in recent years in many tropical countries, 
with a growing network of highways facilitating the entering of settlers, hunters/poachers and loggers into the heart of the mature forests. Therefore, the fragmentation of forests is becoming increasingly widespread with substantial changes in forest dynamics, structure, composition and microclimate [1,5-7]. These alterations also negatively affect a wide variety of animal species.

The forests of the Lao People's Democratic Republic (Laos) are threatened by rapid anthropic development, a changing economy and a growing population [8-11]. This country lost $8.4 \%$ of its primary forest between 2001 and 2018, with a primary forest/total tree cover of $48 \%$ (https: / / rainforests.mongabay.com/deforestation/archive/Laos.htm; last accessed on 24 April 2021). Due to unsustainable deforestation [12] and bushmeat consumption, the forests of Lao PDR are becoming increasingly empty [13-15], and many forest species are threatened [16-18]. Indeed, several studies have defined the Lao forests as affected by an "empty forest syndrome", a condition in which forests that are apparently well preserved but almost devoid of vertebrate fauna due to extreme exploitation by local communities [16-18].

Among the forest taxa targeted by hunting and that are affected by deforestation are those belonging to the primate genus Trachypithecus, which includes 14 Asian species of herbivorous arboreal species [19]. The Laotian langur Trachypithecus laotum (Figure 1) is endemic to Lao PDR [20]. This species is mainly restricted to karst forest habitats in northwestern Khammouane province and in southwestern Bolikhamxai province in central Laos [21]. Recently, T. laotum was categorized as Endangered by IUCN [22] and is listed on CITES Appendix II as well as under protection by the Lao wildlife and aquatic law No 07/NA dated 24 December 2007; it is categorized under the category "prohibited" on the threatened species list under the name T. francoisi sensu lato [23].

Given the threatened status of the Laotian langur and the scarce knowledge available on its ecology and population status, we (1) conducted several field surveys in one of the few presence areas for this primate species (Phou Hin Poun National Protected Area, Khammouane), and (2) compare our results to previous surveys that were conducted in the same territory during previous decades. Our objectives are to (1) provide information about the species distribution, ecology and conservation status at the study area, and (2) to collect data on the local knowledge of the ecology of the species as gathered from interviews with local people.

More specifically, we ask the following research questions:

(i) What is the density of the Laotian langur groups in the study area? Although scientists primarily use presence and absence data for conservation planning of species even in large landscapes, we can obtain a much better and accurate conservation planning if we include data on individual species abundance or density in the favored habitats [24].

(ii) What is the current group size of these monkeys, and has the average group size changed in the last twenty years in the study area? Although all studies on this species at Phou Hin Poun National Protected Area have been short-term, they have spread since 1994. Hence comparisons of the various collected datasets may show population size and conservation status trends. Given the heavy rates of deforestation and overhunting in Lao PDR [8-11], we predict that the group size of langur may be smaller nowadays than $20+$ years ago, thus revealing an overall declining population.

(iii) Are Laotian langur groups sympatric with other primates, and if so, what are their interspecific interactions? Threatened species may suffer from interspecific competition with closely related species, representing a further threat to their conservation. In addition, Laotian forests are inhabited by a rich diversity of primate species [25]. Thus it is likely that the Laotian langur groups should share their habitat with other primate species. 
Based on the answers that we obtained from the three questions mentioned above, we herein address the conservation perspectives for the target species in the study area are. It is expected that this contribution may serve to implement an action plan for T. laotum in Lao PDR.

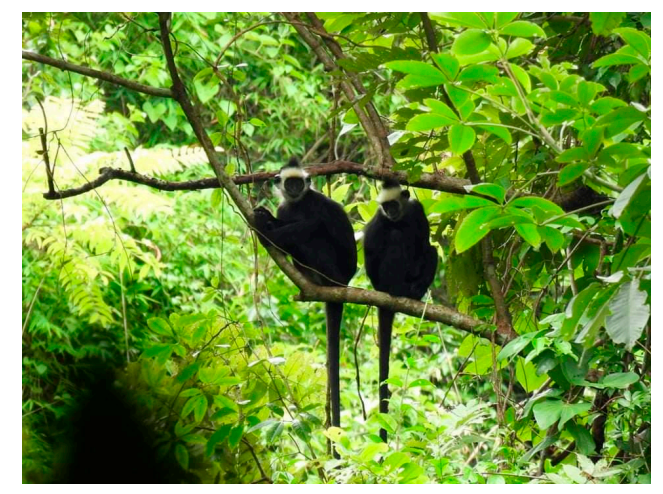

Figure 1. Individuals of the Laotian langur Trachypithecus laotum at the study area.

\section{Materials and Methods}

\subsection{Study Area}

We studied the Laotian langur in Phou Hin Poun National Protected Area (hereby PHPNPA). This area, situated in northwestern Khammouane province $\left(17^{\circ} 26^{\prime}-18^{\circ} 05^{\prime} \mathrm{N}\right.$ and $104^{\circ} 25^{\prime}-105^{\circ} 10^{\prime} \mathrm{E}$ ), was formerly known as Khammouan Limestone National Biodiversity Conservation Area (Khammouan Limestone is called Phou Hin Poun in Lao) and declared in 1993. It covers a total actual area of 225,000 ha, mainly of spectacular karst formations situated at 180-850 m elevation, with pockets of tall mature forest in the valleys and depressions within the rocks [8]. The total area of the park is 150,000 ha (Decree 164). This area contains the largest habitat of the Laotian langur population in the country. The topography of depressions is flat, which contrasts with the surrounding. Depressions often contain primary and secondary mixed deciduous/semi-evergreen forest and less commonly deciduous dipterocarp forest [21]. However, the remaining langur habitat in PHP-NPA has become highly fragmented due to human destruction because many settlements are located on the adjacent plains and river valleys. In addition, agricultural fields often extend up to the base of the karst rocks, and timber and non-timber forest products are collected within the forests of the karst area. We surveyed the central part of the PHP-NPA both inside and edge of the total protection zone (TPZ). TPZ has the best quality forest in this protected area and covers approximately $351 \mathrm{~km}^{2}$ [26], which accounts for about $15.6 \%$ of the actual park area. We selected this area for our surveys not only because of its pristine forest habitat but also because it has flat terrain and good accessibility. In the study area, the wet season was from June to October and the dry season from November to May. The rainfall peaks were in August (mean = $476.3 \mathrm{~mm}$ ) and October $(436 \mathrm{~mm})$, whereas the lowest rainfall occurred in December $(16.3 \mathrm{~mm})$ and February $(19.7 \mathrm{~mm})$, with the monthly average precipitation being $149.8 \mathrm{~mm}$.

\subsection{Interviews and Historical Records}

From 27 July to 1 August 2020, we interviewed 31 people (2 women, 29 men). These were 14 people belonging to the staff of six District Agriculture and Forestry Offices (DAFO, i.e., Hinboun, Khounkham, Nakai, Yommalath, Mahaxay and Thakhek), and 17 villagers, including three from Ban Natan (Nakai district), six from Ban Konglor (Khounkam district), three from Ban Buamlou, one from Ban Bo Neng and four from Ban Kuankacha (Hinboun district). We conducted standardized interviews with the above-mentioned people to determine the presence of primates in their monitored areas. To facilitate the process, we used photos of the various primate species potentially occurring in the area, uploaded on a smartphone. We showed photos of the following species: Laotian langur (T. laotum), black 
langur (Trachypithecus ebenus), southern white-cheeked gibbon (Nomascus siki), stump-tailed (Macaca arctoides) and Assamese (Macaca assamensis) macaques. During the interviews, we used the local names for each species: Laotian langur $=$ khoung, black langur $=$ khong, gibbon $=$ tha nee, Assamese macaque $=$ ling kang, stump-tailed macaque $=$ ling nar daeng . Each interviewee was asked ten questions (see online Supplementary Table S1).

We spent about two hours interviewing the various members of the DAFO staff in each district and the villagers at survey camps. Interviews were authorized by the Department of Forestry of the Lao Government (protocol no. 3111, approved on 26 June 2020). We did not ask the age of the respondents. All eight DAFO interviewees in three districts (Khounkham, Nakai and Hinboun) correctly identified the Laotian langur. Still, two DAFO people in Yommalath correctly identified another species (T. ebenus) but thought that T. laotum and T. ebenus belonged to the same species. Two DAFO staff in Thakhek incorrectly identified the langurs but correctly identified the gibbon. Two other staff in Mahaxay did not know the Laotian langur at all. All villagers correctly identified the Laotian langur, but they also knew and correctly described its vocalization sound and its sleep sites (defined by direct observations) and identified some plant species eaten by the langur.

Based on the information we gathered from the interviewees, we defined some areas of the potential presence of T. laotum in the PHP-NPA. We established a field survey team to identify the areas to be carefully surveyed in each district.

We also compiled a list of all the historical species' observation sources inside the protected area [21,27].

\subsection{Field Surveys}

We focused our surveys in the central part (TPZ) of the PHP-NPA and divided the survey area into four sectors: (1) Konglor-Natan, (2) Konglor, (3) Buamlou and (4) Kuankacha sites (Figure 2) to observe the study species and record their locations, group sizes and threats. The length of each transect is summarized in the online Supplemental Table S2. Field surveys were carried out during the period from August to December 2020. Our team of 18 survey participants, including one main researcher, one person from the Provincial Agriculture and Forestry Office (PAFO), 4 from DAFO offices and 12 villagers, spent 37 days in the field.

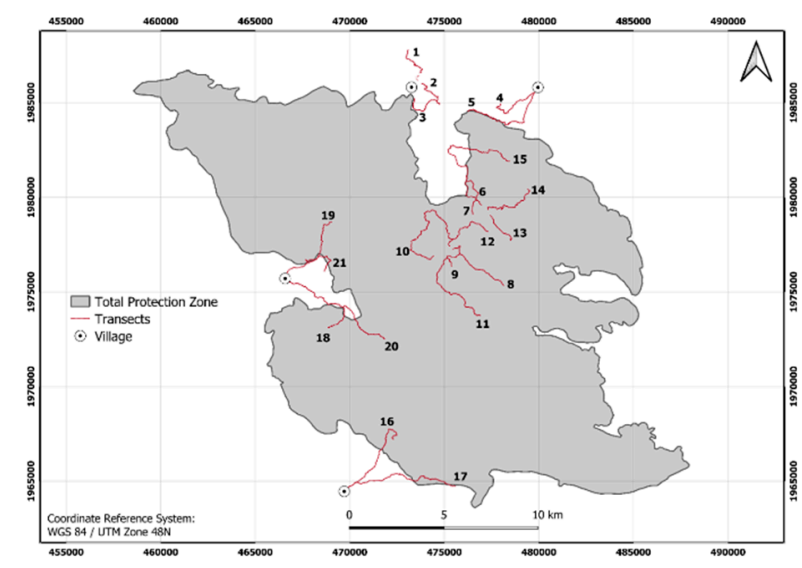

Figure 2. Map of the study area, including the 21 transects that were walked at the four sectors (Konglor-Natan, Konlgor, Buamlou and Kuankacha) of the Phou Hin Poun National Protected Area, Laos.

During the field surveys, we tried as much as possible to use a line transect methodology [28]. However, walking along a straight transect line was impossible in the limestone area in PHP-NPA. So we were forced to use often existing local trails as transects throughout the surveys. Overall, we walked $64.1 \mathrm{~km}$ along 21 transects (Figure 2). Our team walked silently along transects from about 7:00 to 17:00 P.M. For each sector, we conducted 
from 2 to 10 surveys along each transect. Since PHP-NPA has practically no sources of water for the survey team to drink in the dry season, we were forced to make the fieldwork only in the wet season (August to October 2020), but, due to the adverse weather (heavy rainfall making very dangerous to walk on karst areas), we had to postpone our working schedule and continued the field surveys to December 2020. The field surveys were carried out from 13 August to 17 December 2020.

The visibility was grossly similar in the four sectors of the study area, with a mean detection distance being about $150-200 \mathrm{~m}$ for direct sightings and $300-400 \mathrm{~m}$ for calls. For each observed group, we recorded the number, sex, and age of the individuals and the GPS coordinates, the altitude of the sighting spots (m a.s.l.), the time of sightings (Vientiane standard time), and the estimated distance from the observers. We classified the age classes of the observed langur individuals' age based on (1) body size, (2) fur color, and (3) sexual organs. Adult males are much larger in body size, with visible penis and with the breast being fully covered by fur. Adult females are clearly smaller in body size and with two breasts that can be easily seen at their chest and with no penis. Subadults of the two sexes are similar to adults of their respective sex, but with medium body size. Juveniles have a variable fur color, from yellowish or orange to black and white; the body and the tail are yellowish to black, and the head has three colors, yellowish, white and black. In contrast, the adults are black in the body and black and white in the head (online Supplemental Figure S2). In addition, the juveniles are normally spending their time nearby the adult females. Infants have orange or gold fur color and are carried by their mothers. We used the GPS device to mark the coordinate with altitude from a standing point and then used a laser rangefinder to measure the height from the standing point to the spotted animal above the transect. Then, the elevation of observer + elevation from observer to animal $=$ estimated elevation .

\subsection{Statistical Analyses}

Correlations between group size and (i) elevation ( $\mathrm{m}$ a.s.l.) of the sighting spots or (ii) year of observation were assessed by Spearman's rank correlation coefficient after having verified by Kolmogorov-Smirnov test that the two sets of variables did not attain normality and homoscedasticity. The effect of the yearly period of surveys (three groups: 1990s, 2010s, and 2020) on the group size was analyzed by Friedman ANOVA, followed by Mann-Whitney $U$-test for pairwise comparisons. To evaluate the diel activity patterns of the study species, we divided the daily time into 2-h-long sections. We then compared the frequencies of sightings across time sections with a contingency table $\chi^{2}$ test. In the text, means are presented \pm 1 standard deviation, with alpha set at $5 \%$. All statistical analyses were made using SPSS 11.0 software version.

\section{Results}

\subsection{Interviews and Historical Records}

Interviewees in Hinboun, Khounkham and Nakai confirmed the presence of the Laotian langur in their districts. In contrast, interviewees in Yommalath and Thakhek were unsure about this species' presence in their districts. Both Laotian langur and black langur are suspected to occur in these two latter districts without any firm evidence. DAFO teams confirmed that no Laotian langur can be found in the Mahaxay district. Table 1 summarizes the interview results by village, including the identified threats and the feeling that interviewees had on the species' population status.

Table 2 summarizes the historical observations of the study species within the study area. Overall, and after excluding sightings with no number of observed individuals available, 38 sighting events of the Laotian langur in the study area between 1994 and 2010 (Table 2). Statistical comparisons of historical records with our current data are provided below. 
Table 1. Species occurrence and threats as emerged from interview results. For more details, see the text.

\begin{tabular}{|c|c|c|c|c|c|}
\hline District & Village & Occurrence & Threats & Population & Interviewees \\
\hline \multirow{4}{*}{ Hinboun } & Ban Pheepaeng & T. laotum, N. siki, Macaque indet. & Hunting/poaching & Decreased & DAFO staffs \\
\hline & Ban Huana & T. laotum, N. siki, Macaque indet. & Hunting/poaching & Unknown & DAFO staffs \\
\hline & Ban Buamlou & T. laotum, N. siki, Macaque indet. & Hunting/poaching & Unknown & DAFO staffs; villagers \\
\hline & Ban Bo Neng & T. laotum, Macaque indet. & Hunting/poaching & Decreased & Villagers \\
\hline \multirow{3}{*}{ Khounkham } & Ban Konglor & T. laotum, N. siki, Macaque indet. & Hunting/poaching/logging & Decreased & DAFO staffs; villagers \\
\hline & Ban Or & T. laotum & Hunting & Decreased & DAFO staffs \\
\hline & Ban Kateup & T. laotum, N. siki, Macaque indet., serow sp. & Hunting & Unknown & Villagers \\
\hline \multirow{3}{*}{ Nakai } & Ban Natan & T. laotum. Macaque indet. & Poaching & Decreased & DAFO staffs; villagers \\
\hline & Ban Kuam Sam & T. laotum & Unknown & Unknown & DAFO staffs \\
\hline & Ban Vanghin & T. laotum & Unknown & Unknown & DAFO staffs \\
\hline Yommalath & Ban Kuanphan & T. ebenus, Macaque indet., maybe T. laotum & Hunting & Unknown & DAFO staffs \\
\hline \multirow{2}{*}{ Thakhek } & Ban Doi & T. laotum, N. siki, maybe T. ebenus & Hunting & Decreased & DAFO staffs \\
\hline & Ban Phalem & T. laotum, N. siki, maybe T. ebenus & Hunting & Decreased & DAFO staffs \\
\hline
\end{tabular}

Ban = Village; DAFO = District Agriculture and Forestry Office; Number of interviewees (31 people): 14 DAFO staffs + 17 villagers. 


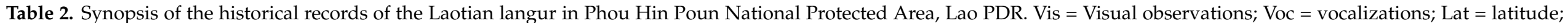

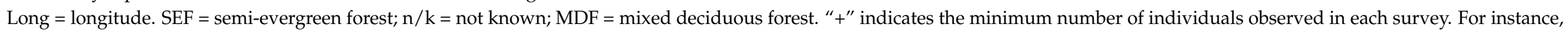

$1+$ would indicate that at least one individual was observed in that given survey.

\begin{tabular}{|c|c|c|c|c|c|}
\hline Location & Lat and Long & Date & Habitat & Group Size & Type \\
\hline Un-named & $17^{\circ} 58^{\prime} 104^{\circ} 49^{\prime}$ & 21 December 1994 & Open karst vegetation & $1+$ & Vis \\
\hline Un-named & $18^{\circ} 02^{\prime} 104^{\circ} 47^{\prime}$ & 21 December 1994 & Open karst vegetation & $1+$ & Vis \\
\hline Near Ban Vang dao & $18^{\circ} 05^{\prime} 104^{\circ} 32^{\prime}$ & 16 May 1995 & Open karst vegetation & $8+$ & Vis \\
\hline Near Ban Vang dao & $18^{\circ} 03^{\prime} 104^{\circ} 31^{\prime}$ & 17 May 1995 & $\mathrm{n} / \mathrm{k}$ & $\mathrm{n} / \mathrm{k}$ & Voc \\
\hline Khua Din & $17^{\circ} 50^{\prime} 104^{\circ} 50^{\prime}$ & 6 February 1996 & $\mathrm{n} / \mathrm{k}$ & probably several groups & Voc \\
\hline South of Khua Din & $17^{\circ} 49^{\prime} 104^{\circ} 50^{\prime}$ & 7 February 1996 & SEF & $8+$ & Vis \\
\hline South of Ban Ak & $17^{\circ} 52^{\prime} 104^{\circ} 52^{\prime}$ & 8 February 1996 & Karst ridge & $\mathrm{n} / \mathrm{k}$ & Vis \\
\hline South of Ban Ak & $17^{\circ} 52^{\prime} 104^{\circ} 53^{\prime}$ & 9 February 1996 & $\mathrm{n} / \mathrm{k}$ & $\mathrm{n} / \mathrm{k}$ (probably several groups) & Voc \\
\hline Near Nam Hinboun & $18^{\circ} 01^{\prime} 104^{\circ} 26$ & 31 January 1998 & Karst above degraded SEF & 9 & Vis \\
\hline Tham Pai & $17^{\circ} 51^{\prime} 104^{\circ} 52$ & 16 March1998 & MDF near cliff & $\mathrm{n} / \mathrm{k}$ & Voc \\
\hline Tham Pai & $17^{\circ} 52^{\prime} 104^{\circ} 52^{\prime}$ & 21 March 1998 & SEF on ridge & $\mathrm{n} / \mathrm{k}$ & Voc \\
\hline Khua Din & $17^{\circ} 50^{\prime} 104^{\circ} 50^{\prime}$ & 18 March 1998 & SEF near cliff & $15-20$ & Vis \\
\hline Khua Din & $17^{\circ} 50^{\prime} 104^{\circ} 50^{\prime}$ & 20 March 1998 & SEF not near cliff & $15-20$ & Vis \\
\hline Khua Din & $17^{\circ} 50^{\prime} 104^{\circ} 50^{\prime}$ & 19 March 1998 & SEF & Probably 2 group & Vis \\
\hline Khouan Huy & $17^{\circ} 42^{\prime} 104^{\circ} 48^{\prime}$ & 2 April 1998 & Boulders at cave mouth & $2+$ (heads not seen) & Vis \\
\hline Khouan Huy & $17^{\circ} 41^{\prime} 104^{\circ} 49^{\prime}$ & 1 April 1998 & Cliff face vegetation & $\mathrm{n} / \mathrm{k}$ & Voc \\
\hline Zone 1_Camp 1 & & 2010 & & 5 calls; 2 groups ( 8 individuals) & Vis \\
\hline Zone 1_Camp 2 & & 2010 & & 2 calls, 1 group (4 individuals) & $\mathrm{Vis}+\mathrm{Voc}$ \\
\hline Zone 1_Camp 3 & & 2010 & & 4 calls, 1 group ( 5 individuals) & $\mathrm{Vis}+\mathrm{Voc}$ \\
\hline Zone 2_Camp 6 & & 2010 & & 1 call & Voc \\
\hline Zone 3_Camp 7 & & 2010 & & 2 calls & Voc \\
\hline Zone 3_Camp 8 & & 2010 & & 2 calls & Voc \\
\hline Zone 3_Camp 9 & & 2010 & & 1 call, 1 group ( 4 individuals) & $\mathrm{Vis}+\mathrm{Voc}$ \\
\hline Zone 3_Camp 10 & & 2010 & & 2 calls & Voc \\
\hline Zone 3_Camp 11 & & 2010 & & 1 call, 1 group ( 6 individuals) & $\mathrm{Vis}+\mathrm{Voc}$ \\
\hline Zone 3_Camp 12 & & 2010 & & 1 call & Voc \\
\hline Zone 3_Camp 13 & & 2010 & & 2 calls, 1 group (6 individuals) & Vis + Voc \\
\hline Zone 4_Camp 14 & & 2010 & & 1 call & Voc \\
\hline Zone 4_Camp 15 & & 2010 & & 2 calls, 1 group ( 8 individuals) & Vis + Voc \\
\hline Zone 4_Camp 16 & & 2010 & & 2 calls, 2 groups (12 individuals) & $\mathrm{Vis}+\mathrm{Voc}$ \\
\hline Zone 4_Camp 17 & & 2010 & & 1 call, 1 group ( 6 individuals) & $\mathrm{Vis}+\mathrm{Voc}$ \\
\hline Zone 4_Camp 18 & & 2010 & & 1 call, 1 group (5 individuals) & Vis + Voc \\
\hline Zone 5_Camp 19 & & 2010 & & 3 call, 3 groups ( 21 individuals) & $\mathrm{Vis}+\mathrm{Voc}$ \\
\hline Zone 5_Camp 20 & & 2010 & & 3 call, 3 groups ( 15 individuals) & $\mathrm{Vis}+\mathrm{Voc}$ \\
\hline
\end{tabular}




\subsection{Field Surveys}

Details of walked transects and locations of the Laotian langur groups are given in the online supplemental Figure S1. Figure 3 shows the total sightings and vocalization locations. Statistics of sightings we made of the Laotian langur in each sector of the study area are compiled in Table 3. Sightings and calls were recorded at a mean distance from observers $=209.5 \pm 101.6 \mathrm{~m}(n=19) .40 \%$ of the sightings were done between $06: 00$ and 08:00, 20\% between 08:01-10:00, 15\% between 10:01-12:00, and 25\% between 14:01-16:00, with no sightings after 16:00. There were no significant differences in the frequency of sightings across 2-h-long daily phases $\left(\chi^{2}=5.58, \mathrm{df}=4, p=0.232\right)$.

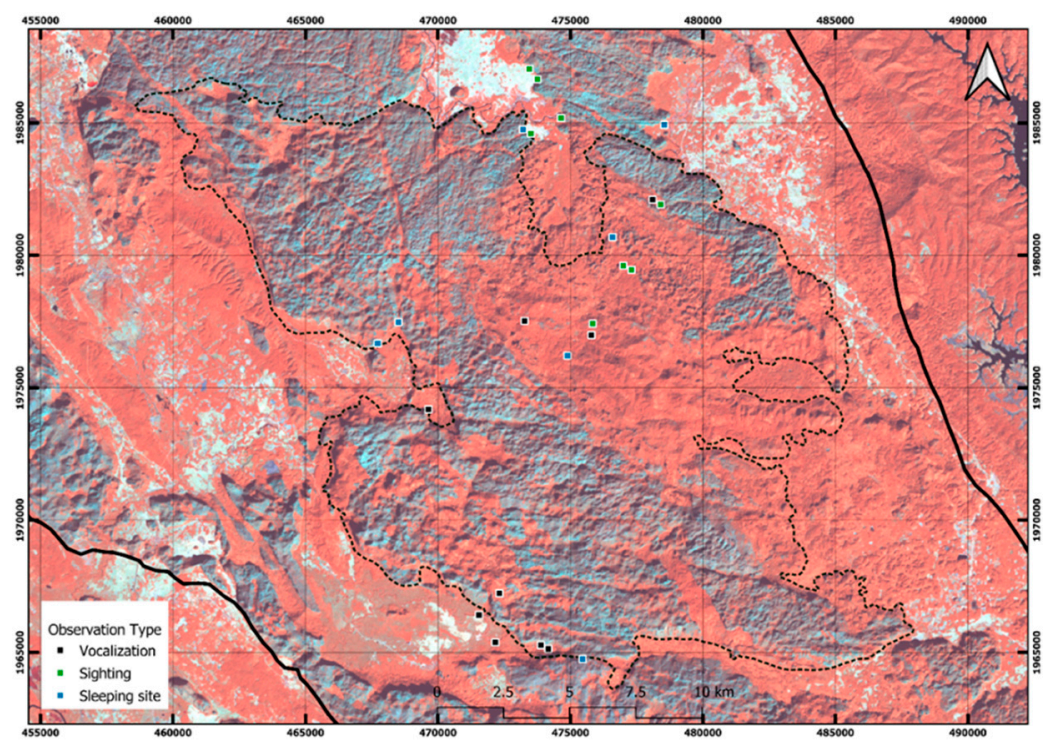

Figure 3. Sighting locations of the Laotian langur using Landsat 8 images. These images were taken from 22 January 2021 with bands 5-4-3 combination.

Table 3. Laotian langur encountered on trails walked in each sector. In this table, we include both the directly observed groups and those recorded by vocalizations during our surveys. For these latter groups, it was impossible to determine the size, sex or age of their members.

\begin{tabular}{cccc}
\hline Sectors (Total Effort) & $\begin{array}{c}\text { Frequency of Encountered } \\
\text { Groups }\end{array}$ & No. of Individuals & $\begin{array}{c}\text { Encounter Rates } \\
\text { (Groups Per km Walked) }\end{array}$ \\
\hline Konglor-Natan $(14.9 \mathrm{~km})$ & 5 & 17 & 0.34 \\
Konglor $(32.8 \mathrm{~km})$ & 7 & 22 & 0.21 \\
Buamlou $(5 \mathrm{~km})$ & 5 & 6 & 1.00 \\
Kuankacha $(11.4 \mathrm{~km})$ & 2 & 2 & 0.18 \\
\hline
\end{tabular}

The mean encounter rate of the langur groups, including those directly observed and those that were just heard, was $0.432 \pm 0.38 \mathrm{~km}^{-1}$ (Table 3). Encounter rates were much higher at Buamlou than in the other sectors (Table 3). However, our samples are too small for any statistical evaluation. In total, we counted nine Laotian langur groups (35 individuals) that were directly observed. In these directly observed groups, we recorded 24 adults of both sexes, 10 subadults of both sexes and one juvenile. Group size ranged from 2 to 6 individuals (Table 4). However, larger group sizes (up to 20-25 individuals) were observed in the study area in 1998 (Table 2). Although overall group size did not vary significantly among the three yearly periods (Friedman ANOVA, $\chi^{2}=5.1, p=0.079$ ), there was a significant decrease of group size between 1994 and 2020 (Mann-Whitney pairwise comparison: $p=0.010$ ), whereas there was no difference between the 2010s and 2020 (Mann-Whitney pairwise comparison: $p=0.250$ ). The various individuals/groups were observed at a mean elevation $=313.8 \pm 147.6 \mathrm{~m}$ a.s.l. $(\mathrm{n}=19)$, and there was no 
correlation between size of the various groups and elevation (Spearman $r_{\mathrm{s}}=0.056, \mathrm{n}=19$, $p=0.816)$.

Table 4. Group size of the Laotian langur directly observed during this study.

\begin{tabular}{|c|c|c|c|c|c|c|c|c|}
\hline \multirow[t]{2}{*}{ Group No. } & \multirow[t]{2}{*}{ Location } & \multicolumn{2}{|c|}{$\begin{array}{c}\text { Coordinate (GPS) WGS } \\
\text { 84/UTM Zone } 48 \mathrm{~N}\end{array}$} & \multirow[t]{2}{*}{ Adults } & \multirow{2}{*}{ Subadults } & \multirow[t]{2}{*}{ Juveniles } & \multirow[t]{2}{*}{ Infants } & \multirow[t]{2}{*}{ Group Size } \\
\hline & & Northing & Easting & & & & & \\
\hline 1 & Tham Kuay & 473,753 & $1,986,651$ & 2 & 0 & 0 & 0 & 2 \\
\hline 2 & Tham Huator & 473,457 & $1,987,041$ & 3 & 2 & 0 & 0 & 5 \\
\hline 3 & Near Konglor cave & 474,646 & $1,985,180$ & 3 & 1 & 0 & 0 & 4 \\
\hline 4 & Poung Ta Tid Pha & 473,512 & $1,984,602$ & 3 & 0 & 0 & 0 & 3 \\
\hline 5 & Tham Huator & 473,753 & $1,986,651$ & 2 & 1 & 0 & 0 & 3 \\
\hline 6 & Pha Soung & 476,995 & $1,979,610$ & 2 & 2 & 0 & 0 & 4 \\
\hline 7 & Ang Nam Ta Ngon & 475,844 & $1,977,413$ & 4 & 2 & 0 & 0 & 6 \\
\hline 8 & Ang Khee Ther & 477,304 & $1,979,456$ & 2 & 1 & 0 & 0 & 3 \\
\hline 9 & Kuan Dik & 478,413 & $1,981,923$ & 3 & 1 & 1 & 0 & 5 \\
\hline Total & & & & 24 & 10 & 1 & 0 & 35 \\
\hline
\end{tabular}

\subsection{Observations on Sympatry with Other Primates}

During the field surveys, we observed closely sympatric populations of the Laotian langur and Assamese macaque. Individuals of these two species used the same forest karst and even the same tree for feeding (Figure 4). At Tham Huator, we observed a group of the Laotian langur with three individuals eating the young leaves on trees. A group of five individuals of Assamese macaques came to the feeding tree site with a loud noise. It forced the langur group to abandon the tree within a few minutes of the interaction. We observed that the Laotian langur fed by early morning and finished feeding before the arrival of the macaque groups for feeding. Langurs were observed to feed mainly upon young tree leaves. In contrast, macaques preferred foraging upon leaves, but, including flowers of trees and flowers from vines, and they did not forage upon the same young tree leaves as the langur did at this site. Thus, it is possible that a food niche partitioning may occur between these two species. On another occasion, we observed a group of six individuals of langurs and a group of five individuals of macaques on the same tree for feeding in the morning. They did not fight each other, but we noticed that most langurs sat on branches in the middle of the canopy, eating young leaves. In contrast, most macaques occupied branches at the lower level of the tree canopy.

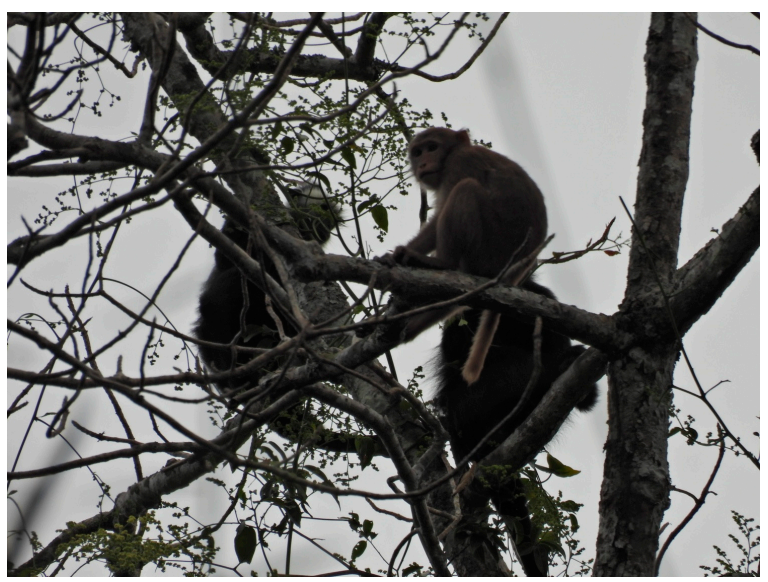

Figure 4. Laotian langur (on the left) and an Assamese macaque (on the right) interacting in the same tree. The two species are sympatric in several sites of the protected area where surveys were carried out. 
In another case, we encountered a group of langurs at a site along transect 10; on the next day, at the same site, there were no langurs but a group of Assamese macaques that were feeding at the same site. We also heard macaque's vocalization and sighted the langurs at the same site along transect 15.

We observed langur individuals eating leaves at seven different and independent times during the field survey. On two of these occasions, the langur and the macaques were eating in the same spot.

\subsection{Observations on Threats}

Although not quantified, we observed logging in all four sectors of the study area. In particular, we recorded large numbers of valuable tree logging (Diospyros embryopteris) and other hardwood species from Konglor-Natan and Konglor sites. Ongoing logging of Afzelia xylocarpa and Dalbergia cultrata was mainly found at the Konglor site, where it occurred even far from the village. Many trails, camps and trash (energy drink cans, cigarettes, etc.) were also distributed inside the total protection zone. In addition, mining companies are operating in the Hinboun district. These companies have been implementing mining extraction activities close to Ban Kuankacha and built a new road for trucks to access the mining site. The mining site is located very close to the boundaries of the total protection zone and, therefore, potentially represents a source of disturbance for langur groups. Roads and trails also fragment the potential forest habitat of langurs.

We did not directly observe poaching during our survey. Still, it was reported by local villagers and confirmed by photos provided by hunters (Figure 5). In Ban Natan, it was reported that they hunted a group of 12 individuals nearby the local primary school in 2018. In Ban Konglor, a villager reported that, between the years 2000 and 2010, he and his friend spent many months in the protected area searching for agarwood tree and other valuable trees. Meanwhile, they killed at least 500 individuals of various primate species, including langurs, macaques, gibbon and loris from the NPA. He also reported that another group of poachers also killed above 200 additional primate individuals during the same time interval. In Ban Buamlou, villagers reported that the langur meat is consumed by families, and langur bones normally were sold for approximately 80,000 Kip/kg (approximately USD 9-10) to some Vietnamese shops in Ban Songhong. Other signals of poaching were that, for instance, in Ban Kuankacha, our survey team found two guns in the Kuankacha sector, and other guns were also found in other sectors of the surveyed territory. These guns were confiscated by the rangers of the protected area.

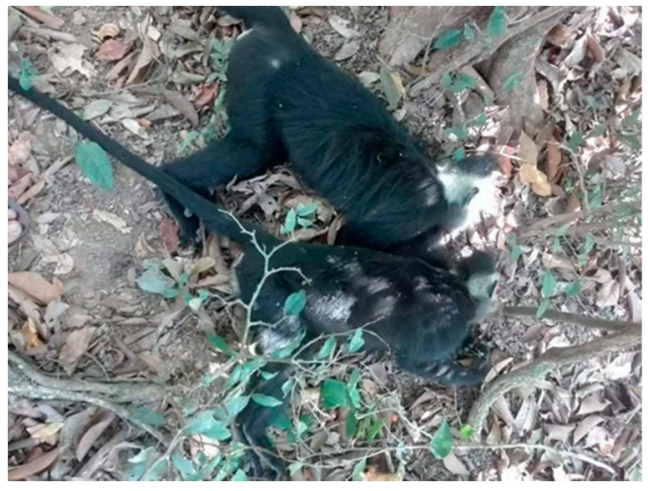

A

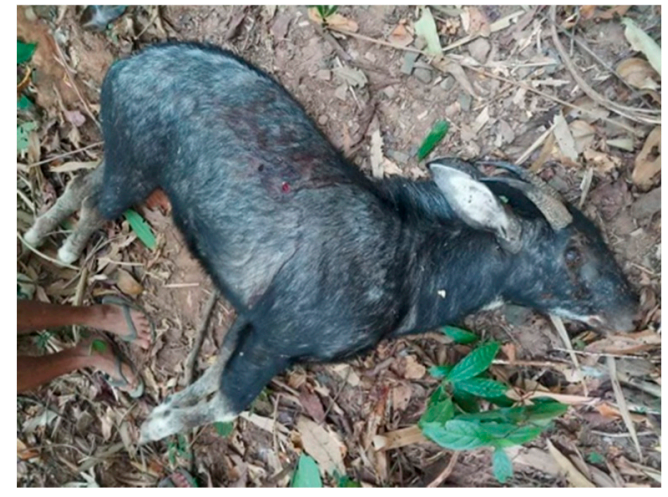

B

Figure 5. Evidence of poaching within the protected area. Poaching is still one of the main threats to the survival of wildlife. In this figure: (A): two Laotian langur killed in Ban Natan; (B): serow killed in Hinboun. Photos obtained from anonymous hunters. 


\section{Discussion}

Through the survey period from August to December 2020, we walked $64.1 \mathrm{~km}$ of 21 transects and recorded 35 langur individuals in 9 troops. The highest encounter/detection rate of the Laotian langur was at the Buamlou site (1 group per $\mathrm{km})$. In contrast, it was much lower at Konglor-Natan $(0.34$ group $/ \mathrm{km})$, Konglor $(0.21$ group $/ \mathrm{km})$ and Kuankacha $(0.18$ group $/ \mathrm{km})$. No data are available for Laos in the past as the previously conducted survey aimed at understanding the species/subspecies distribution in the PHP-NPA [27] and not to estimate the relevant abundance of the various primates [27]. In 2010 Phiapalath [27] recorded 26 groups in 21 survey points. However, the current survey shows relatively similar encounter rates as those that were provided for conspecifics in the Phong Nha-Ke Bang National Park (0.19 to 0.48 group $/ \mathrm{km}$; see [29]) and for Trachypithecus germaini in Vietnam (range 0.21-1.15 group $/ \mathrm{km}$; [30]).

Compared to previous studies, group sizes observed at our study site in 2020 were much lower than those recorded in the Quang Binh Province, Vietnam (15 or more; see [31]), but similar to the size of langur groups observed by [32] (mean 7.3), by [31] (mean 8.2) and by [33]. The closely related Trachypithecus delacouri is territorial as probably also the Laotian langur is, and usually lives in single-male-multifemale groups of 5-30 individuals [34]. However, even subtle differences in survey technique may produce different results. Interestingly, comparing the historical dataset with the present survey results on the langur population from the study area, we found a significant decline in the number of individuals in each group (at least between 1994 and 2020). Although we do not have firm evidence of the reasons behind this pattern, it seems likely that this is a signal of overall population size decrease throughout the years. In addition, Table 4 shows that we observed just one juvenile and no infants. This demographic skew may indicate a declining population and perhaps unusual mortality pressures on younger aged langurs or possibly reflect a birth season not covered by our surveys [35]. Further surveys should confirm these population trends, but also circumstantial evidence provided by villagers may suggest an ongoing population decline of langur. For instance, (i) in Ban Natan, the langurs could be observed easily when they were feeding on the cliffs near the village to about 2010, but now it is hard to see them because villagers poached them, and (ii) there was a general feeling of our interviewees that the population of these monkeys is declining.

Based on the preliminary data provided in the present study, it is impossible to fully evaluate the population status of the study species in the study area. However, since langur groups were observed in a wide portion of the protected area (i.e., in all the four investigated sectors), it is likely that the species may still be relatively common at the local scale. In one sector (Buamlou), the encounter rates were similar to the highest rates recorded by [30], suggesting that Buamlou may be a crucial area to be protected if we want to guarantee the survival of the study species in the area. Buamlou sector is suitable for both the Laotian langur and the gibbon due to its inaccessibility. The rugged and steep terrain naturally protects these animals and makes it difficult for humans to access the site. Gibbon density in the Buamlou sector is higher than in other sectors of the NPA [36,37].

Interestingly, our study also showed that langurs can be sympatric and even use the same foraging and sleep sites as the Assamese macaques. A study of the coexistence mechanisms of these two species would be extremely interesting. Still, our preliminary observations may indicate that these two species may exhibit some kind of niche partitioning for both food types (eating preferentially different stages of leaves and flowers on the same tree) and foraging microhabitat (occupying different areas of the canopy when on the same tree). However, the Assamese macaque is essentially a young-leaves-eater in limestone habitats in China [38,39], but may also feed abundantly on fruits [40,41] and may opportunistically take a wide range of food types, including human food [41]. In contrast, the Laotian langur is typically folivorous (based on our small number of observations). Interestingly, François' langurs (T. francoisi) showed a more flexible diet composition than sympatric Assamese macaques. They increased dietary diversity and mature leaf consumption during periods of seasonal young leaves and fruit shortage. In contrast, 
Assamese macaques relied heavily on young bamboo leaves (Indocalamus calcicolus) in most months [42]. Whereas interspecific interactions between sympatric Laotian langur and Assamese macaque were not observed previously, a previous survey [27] revealed that the Laotian langur and the black langur (T. ebenus) occurred sympatrically within the NPA. Based on Phiapalath's [27] observations, T. laotum and T. ebenus were found in the south and southwest (Ban Phalam) of the NPA. Our survey found that the Laotian langur and macaques also shared habitat in the central part of the NPA. In contrast, no T. ebenus was encountered during this survey. Moreover, black langur was observed to occasionally use the same sleep sites with Assamese and stump-tailed macaques in Hin Nam No NPA in 2008 (P. Phiapalath unpublished data). However, it should be borne in mind that our observations are just preliminary. It would be needed a specific methodology and hundreds of hours of observation to truly test niche partitioning between these sympatric species in the wild.

\section{Threats and Conservation Considerations}

Although we did not evaluate the threats quantitatively to langurs in the study area, we suggest that poaching and selective logging in its karst habitats may be the most critical issues to their survival within the PHP-NPA. This was also confirmed by the interviews that we conducted in the study area. Konglor site was the most accessible for local people and logging of valuable tree species. We frequently observed evidence of poaching on the transects inside the TPZ. This site is regularly visited by poachers/loggers because the terrain is easier to access. It has a constant water supply, and it contains large numbers of wild animals and valuable trees. Extensive logging has been throughout the country from 2013 to 2015, and often, it has been associated with hunting/poaching. Fortunately, the logging activity has been effectively banned in Laos since 2016 following the Order of Prime Minister no. 15/PM. Anyhow, TPZ should be prioritized for the conservation of key species in this reserve: indeed, our unpublished observations also showed that it is not only suitable habitat for the Laotian langur but also for southern white-cheeked gibbon (Nomascus siki), stump-tailed macaque (Macaca arctoides), Assamese macaque (Macaca assamensis), Asiatic black bear (Ursus thibetanus), sun bear (Helarctos malayanus), muntjac (Muntiacus sp.), hog badger (Arctonyx collaris), wild boar (Sus scrofa), Indochinese serow (Capricornis sumatraensis maritimus), silver pheasant (Lophura nycthemera), wreathed hornbills (Rhyticeros undulatus), bare-faced bulbul (Nok hualon) and probably black langur (Trachypithecus ebenus). PHP-NPA would hold important populations of other threatened species, including a recent clouded leopard Neofelis nebulosa record [43]. In addition, valuable and rare flora species such Diospyros embryopteris, agarwood Aquilaris sp., dragon's blood Dracaena sp., rosewood Dalbergia cultrata are also found in the TPZ [37].

To save the remaining Laotian langur population in PHP-NPA, there is still much work to be done by the protected area management, especially in Khammouane Province. Currently, IUCN provides technical support to protected area staff to conserve the protected area biodiversity and improve management plans for PHP-NPA and specifically for more effective TPZ management. Currently, IUCN and World Bank projects are supporting the management and biodiversity conservation in PHP. We believe that further research on the population and ecology of the endangered Laotian langur should be conducted, using these funds to better understand species living at TPZ and aid their long-term conservation.

Supplementary Materials: The following are available online at https:/ / www.mdpi.com/article/10 $.3390 /$ d13060231/s1, Figure S1: Field survey trails throughout the various sectors of the study area. Trails walked with locations of the Laotian langur encountered are presented, Figure S2: Coloration differences between adults and juvenile langurs at the study area, Table S1. List of the ten questions forming the standardized questionnaire for the various interviewees at the study area. For more details, see the methods, Table S2. Field effort (in terms of km walked) of each trail during this survey. 
Author Contributions: Conceptualization, H.D.T. and J.S.; methodology, H.D.T., P.P. and J.S.; validation, P.B., formal analysis, L.L.; investigation, J.S., P.B., L.L., T.P.V. and J.S.; writing-original draft preparation, T.P.V., P.B., P.P. and H.D.T. All authors have read and agreed to the published version of the manuscript.

Funding: This research was funded by Rufford Foundation, grant number 29526-1.

Institutional Review Board Statement: Interviews and field surveys were authorized by the Department of Forestry of the Lao Government (protocol no. 3111, approved on 26 June 2020).

Informed Consent Statement: Informed consent was obtained from all subjects involved in the study.

Data Availability Statement: Data are presented in the paper and in the Online Supplemental Materials. The data are not publicly available due to conservation reasons, as the study species has a narrow distribution and maybe subjected to poaching.

Acknowledgments: We are thankful to the Rufford Foundation, which provided funding to undertake this study. We would like to thank the Department of Forestry to allow our team to conduct this study in Phou Hin Poun National Protected Area and also thank the protected area's staffs of the Provincial Agriculture and Forestry Office in Khammouane and District Agriculture and Forestry Offices as well as local people for their assisting the field survey. We also thank the Lao Wildlife Conservation Association for their help in managing the project fund. We are grateful to the staffs and the German International Cooperation (GIZ) adviser at Vietnam National University of Forestry and staff at Faculty of Forestry at the National University of Laos for their valuable advice and support and support, and to four anonymous referees for very helpful comments on the submitted draft.

Conflicts of Interest: The authors declare no conflict of interest.

\section{References}

1. Laurance, W.F.; Vasconcelos, H.L.; Lovejoy, T.E. Forest loss and fragmentation in the Amazon: Implications for wildlife conservation. Oryx 2000, 34, 39-45. [CrossRef]

2. Echeverria, C.; Coomes, D.A.; Hall, M.; Newton, A.C. Spatially explicit models to analyze forest loss and fragmentation between 1976 and 2020 in southern Chile. Ecol. Model. 2008, 212, 439-449. [CrossRef]

3. Liu, Y.; Feng, Y.; Zhao, Z.; Zhang, Q.; Su, S. Socioeconomic drivers of forest loss and fragmentation: A comparison between different land use planning schemes and policy implications. Land Use Policy 2016, 54, 58-68. [CrossRef]

4. Padalia, H.; Ghosh, S.; Reddy, C.S.; Nandy, S.; Singh, S.; Kumar, A.S. Assessment of historical forest cover loss and fragmentation in Asian elephant ranges in India. Environ. Monit. Assess. 2019, 191, 1-13. [CrossRef] [PubMed]

5. Bierregaard, R.O., Jr.; Lovejoy, T.E.; Kapos, V.; dos Santos, A.A.; Hutchings, R.W. The biological dynamics of tropical rainforest fragments. Bioscience 1992, 42, 859-866. [CrossRef]

6. Laurance, W.F. A crisis in the making: Responses of Amazonian forests to land use and climate change. Trends Ecol. Evol. 1998, 13, 411-415. [CrossRef]

7. Laurance, W.F. Reflections on the tropical deforestation crisis. Biol. Conserv. 1999, 91, 109-117. [CrossRef]

8. Timmins, R.J. Notes on Wildlife and Habitats in Khammouan Limestone National Biodiversity Conservation Area, Khammouan Province, Lao PDR 1997; Centre for Protected Areas and Watershed Management/The Wildlife Conservation Society Lao Program: Vientiane, Lao People's Democratic Republic, 1997.

9. Rigg, J.D. Forests, marketization, livelihoods and the poor in the Lao PDR. Land Degrad. Dev. 2006, 17, 123-133. [CrossRef]

10. McNamara, S.; Erskine, P.D.; Lamb, D.; Chantalangsy, L.; Boyle, S. Primary tree species diversity in secondary fallow forests of Laos. For. Ecol. Manag. 2012, 281, 93-99. [CrossRef]

11. Phompila, C.; Lewis, M.; Ostendorf, B.; Clarke, K. Forest cover changes in Lao tropical forests: Physical and socio-economic factors are the most important drivers. Land 2017, 6, 23. [CrossRef]

12. Lamb, D. Deforestation and its consequences in the asia-pacific region. In Regreening the Bare Hills; Springer: Dordrecht, Germany, 2011; pp. 1-39.

13. Long, B.; Gray, T.; Lynam, A.; Seng, T.; Laurance, W.; Scotson, L.; Ripple, W. Reversing 'empty forest syndrome' in Southeast Asia. Natl. Geogr. Voices 2017, 8, 1-6.

14. Pruvot, M.; Khammavong, K.; Milavong, P.; Philavong, C.; Reinharz, D.; Mayxay, M.; Theppangna, W. Toward a quantification of risks at the nexus of conservation and health: The case of bushmeat markets in Lao PDR. Sci. Total Environm. 2019, 676, 732-745. [CrossRef]

15. Zuklin, T.; Maury, N.; Sitthivong, S.; Pham, T.V.; Le Duc, O.; Bordes, C.; Leprince, B.; Ducotterd, C.; Oanh, L.V.; Vilay, P.; et al. The "empty forest syndrome" and the herpetofaunal communities in Laos (South-Eastern Asia). Russ. J. Herpetol. 2021, in press.

16. Johnson, A.; Singh, S.; Duangdala, M.; Hedemark, M. The western black crested gibbon Nomascus concolor in Laos: New records and conservation status. Oryx 2005, 39, 311-317. [CrossRef] 
17. Sacklokham, S.; Dufumier, M. Land-tenure policy, deforestation, and agricultural development in Lao PDR: The case of the Vientiane plain. Moussons. Rech. En Sci. Hum. Sur L'asie Du Sud-Est 2006, 9, 189-207. [CrossRef]

18. Suwannarong, K.; Chapman, R.S.; Lantican, C.; Michaelides, T.; Zimicki, S. Hunting, food preparation, and consumption of rodents in Lao PDR. PLoS ONE 2015, 10, e0133150. [CrossRef]

19. Groves, C. Trachypithecus. In Mammal. Species of the World. A Taxonomic and Geographic Reference, 3rd ed.; Wilson, D.E., Reeder, D.M., Eds.; Johns Hopkins University Press: Baltimore, MD, USA, 2005; pp. 175-178, ISBN 0-8018-8221-4.

20. Timmins, R.J.; Boonratana, R. Trachypithecus laotum. In The IUCN Red List of Threatened Species; The International Union for Conservation of Nature: Gland, Switzerland, 2008; E.T 22044A9350930. Available online: www.iucnredlist.org (accessed on 21 March 2021).

21. Steinmetz, R.; Timmins, R.J.; Duckworth, J.W. Distribution and conservation status of the Lao leaf monkey (Trachypithecus (Fr.) Laotum). Int. J. Primatol. 2011, 32, 587-604. [CrossRef]

22. IUCN. The IUCN Red List of Threatened Species, 2020-2021. IUCN Website. Available online: Iucnredlist.org (accessed on 27 April 2021).

23. Coudrat, C.N.Z.; Nadler, T.; Phiapalath, P.; Duckworth, J.W. Trachypithecus laotum. In The IUCN Red List of Threatened Species; The International Union for Conservation of Nature: Gland, Switzerland, 2020; E.T 22044A1795913. Available online: www. iucnredlist.org (accessed on 21 March 2021).

24. Veloz, S.; Salas, L.; Altman, B.; Alexander, J.; Jongsomjit, D.; Elliott, N.; Ballard, G. Improving effectiveness of systematic conservation planning with density data. Conserv. Biol. 2015, 29, 1217-1227. [CrossRef]

25. Hamada, Y.; Malaivijitnond, S.; Kingsada, P.; Bounnam, P. The distribution and present status of primates in the northern region of Lao PDR. Trop. Nat. Hist. 2007, 7, 161-191.

26. Brakels, P. Summary Report of the Zoning Activities in Phou Hin Poun National Protected Area; IUCN Lao PDR: Vientiane, Lao People's Democratic Republic, 2019.

27. Phiapalath, P. Brief Report of Lao Langur Trachypithecus laotum Survey in Phou Hin Poun National Protected Area, Khammouane Province; Lao Wildlife Conservation Association: Vientiane, Lao PDR, 2010.

28. Brockelman, W.Y.; Ali, R. Methods of surveying and sampling forest primate populations. In Primate Conservation in the Tropical Forest; Marsh, C.W., Mittermeier, R.A., Eds.; Alan R. Liss: New York, NY, USA, 1987; pp. $23-62$.

29. Frankfurt Zoological Society in Vietnam. Biodiversity Survey of the Macaque, Langur and Douq Monkey in and around the Phong Nha-Ke Bang National Park, Quang Binh, Vietnam; Vietnam-Germany Development Cooperation: Hanoi, Vietnam, 2011.

30. Fiore, R.R. A Survey of Indochinese Silvered Langurs (Trachypithecus germaini) in Phu Quoc National Park, Vietnam. Ph.D. Thesis, University of Colorado at Boulder, Boulder, CO, USA, 2015.

31. Ha, N.M. Some observations on the Hatinh Langur, Trachypithecus laotum hatinhensis (Dao 1970), in north central Vietnam. Primate Conserv. 2006, 21, 149-154. [CrossRef]

32. Pham, N.; Do, T.; Truong, V.L. Preliminary survey for Hatinh langur in north central Vietnam. Asian Primates 1996, 6, 13-17.

33. Haus, T.; Vogt, M.; Forster, B. Observations on the Hatinh langur (Trachypithecus hatinhensis) during point and line transect sampling in the Phong Nha-Ke Bang National Park, Central Vietnam. Vietnam. J. Primatol. 2009, 3, 17-27.

34. Harding, L.E. Trachypithecus delacouri (Primates: Cercopithecidae). Mamm. Species 2011, 43, 118-128. [CrossRef]

35. Lhendup, S.; Tshering, U.; Tenzin, J. Population structure and habitat use of golden langur (Trachypithecus geei) in Royal Manas National Park, Bhutan. Int. J. Fauna Biol. Stud. 2018, 5, 97-101.

36. Phiapalath, P.; Bousa, A.; Paul Insua-Cao, P. The Status and Distribution of Gibbons in Phou Hin Poun National Protected Area; Fauna \& Flora International/IUCN Lao PDR: Vientiane, Lao PDR, 2012.

37. Brakels, P. The Status and Distribution of Gibbons in Phou Hin Poun National Protected Area; Fauna \& Flora International/IUCN Lao PDR: Vientiane, Lao PDR, 2019.

38. Zhou, Q.; Wei, H.; Huang, Z.; Huang, C. Diet of the Assamese macaque Macaca assamensis in limestone habitats of Nonggang, China. Curr. Zool. 2011, 57, 18-25. [CrossRef]

39. Huang, Z.; Huang, C.; Tang, C.; Huang, L.; Tang, H.; Ma, G.; Zhou, Q. Dietary adaptations of Assamese macaques (Macaca assamensis) in limestone forests in Southwest China. Am. J. Primatol. 2015, 77, 171-185. [CrossRef]

40. Schülke, O.; Pesek, D.; Whitman, B.J.; Ostner, J. Ecology of Assamese macaques (Macaca assamensis) at Phu Khieo Wildlife Sanctuary, Thailand. J. Wildl. Thail. 2011, 18, 1-15.

41. Koirala, S.; Chalise, M.K.; Katuwal, H.B.; Gaire, R.; Pandey, B.; Ogawa, H. Diet and activity of Macaca assamensis in wild and semi-provisioned groups in Shivapuri Nagarjun National Park, Nepal. Folia Primatol. 2017, 88, 57-74. [CrossRef]

42. Zhou, Q.H.; Huang, Z.H.; Wei, H.; Huang, C.M. Variations in diet composition of sympatric Trachypithecus francoisi and Macaca assamensis in the limestone habitats of Nonggang, China. Zool. Res. 2018, 39, 284-291. [CrossRef]

43. Brakels, P.; Somdachit, T. Record of cats from Phou Hin Poun National Protected Area. IUCN Lao PDR. Cat News $2020,71$. 